Although the present rules are unsatisfactory, they do at least protect the offeree from the offeror's power to revoke. The Dick case may imperil this protection. By rejecting the contention that the post office is the agent of the offeror, the court destroyed one common basis for the "letter of acceptance" rule. ${ }^{20}$ If the "letter of acceptance" rule is set aside, the rejection situation can then be handled in a normal manner. The problem of how to allocate the risk of loss or delay in contracts by correspondence would confront the courts anew. At its best, the Dick case may perform the service of calling attention to the need for a firm offer principle.

\title{
FURTHER RETREAT FROM THE POLEMIS DOCTRINE
}

The House of Lords appears to have hammered another nail into the coffin of the so-called English or "Polemis" rule of proximate cause. Not long after In re Polemis ${ }^{\mathrm{x}}$ established the original rule, the high court initiated a course of qualification and restriction which has now culminated in the recent case of Monarch S.S. Co. v. A/B Karlshamns Oljefabriker. ${ }^{2}$ Thus the House of Lords has raised anew the perplexing question of the extent of liability for negligent acts.

In the Monarch case appellant had contracted to ship a cargo of beans to Sweden prior to World War II. Due to various defects in the vessel which caused her to be unseaworthy, she was still enroute when war broke out. By Admiralty orders the ship was diverted to Scotland where the cargo was transhipped aboard neutral vessels to Sweden. The court allowed the cost of the shipment as damages, basing the award on the principle of "reasonable contemplation," which, apparently, will now replace the "Polemis" rule in the field of torts.

The English retreat from the Polemis doctrine began with Liesbosch, Dredger v. Edison S.S. ${ }^{3}$ There the plaintiff' dredger was moored in a harbor when the defendants' steamship fouled the moorings and carried her out to sea, where she sank and was lost. The plaintiffs had invested all their liquid assets in a contract undertaking; and, unable to buy their own dredger, they were forced to pay a high rate of rent on another which was much more expensive to operate. The plaintiffs included in their claim for damages the loss due to the work stoppage between the date of the sinking and the hire of the dredger, the extra expense in renting, and the added expense in operating the rented dredger. Since the de-

down any fraud which the offeror might undertake. Since the offeror signs the return receipt when he receives the letter of acceptance, he could hardly claim later that he never received the communication.

20 There is, however, no reason to think that a well-advised court will permit the offeror to revoke after the letter of acceptance has been mailed.

[ [rg2r] 3 K.B. 560 .

2 [1949] I All E.R. I. See Bourhill v. Young, [I943] A.C. Iro; Liesbosch, Dredger v. Edison S.S., [I933] A.C. 449; Salmond, Torts I3I-I37 (I0th ed. I945).

3 [r933] A.C. 449 . 
fendants had admitted liability for the original negligence, the question before the court was the extent of liability for the wrong. Lord Wright, speaking for the court, reasoned that the impecuniosity was not traceable to the defendants' acts. ${ }^{4}$ But by failing to relate the ultimate harm only to the defendants' wrongful acts, Lord Wright ignored the plain dictates of the Polemis doctrine. Rather than posing the question of whether the impecuniosity was an effect of the wrong, the House of Lords should have phrased the problem in terms of simple cause and effect. For, under the Polemis rule, a defendant should be responsible for all of the consequences of his negligence which are in the chain of physical causation. This approach, as stated in the three cases of Hambrook v. Stokes, In re Polemis, ${ }^{6}$ and Smith v. London \& Southwestern $R$. Co. ${ }^{7}$ requires that if there is a reasonable inference of negligence, and of a causal connection in fact, the case will go to the jury even if the particular harm complained of was entirely unforeseeable. ${ }^{8}$ In deciding whether there was a causal connection between the negligence and the ultimate harm, it must be determined only whether the harm would not have happened but for the original negligence of the defendant.9

Yet Lord Wright dismissed the Polemis rule as not being relevant to the Liesbosch situation. "That case," he said, "was concerned with the immediate physical consequences of the negligent act, and not with the co-operation of an extraneous matter such as the plaintiffs' want of means." "Io It is difficult to understand what was meant by "immediate physical consequences of the negligent act," and it is also difficult to see how any test could be formulated to determine such. If actual cause and effect was meant, then the reasoning leads back to the "but for" test, which was not applied. But because the House of Lords termed the impecuniosity a "separate and concurring cause, extraneous to and distinct in character from the tort," "rx the defendant in the Liesbosch case was not liable for harm resulting from this factor. Such a conclusion was made possible by employing the familiar technique of "intervening agency." However, in failing to treat the impecuniosity as an existing "condition," even this approach was incorrectly applied. Since a "condition" would depend upon the defendant's conduct to become active, and thus harmful, no new agency can be said to have intervened and have insulated him from liability. ${ }^{12}$ It would appear that the plaintiffs' impecuniosity in the Liesbosch case was such a condition and, therefore, did not intervene to break the chain of cause and effect. The Liesbosch problem was but another variant of Lord Blackburn's hypothetical case: "[I]f a

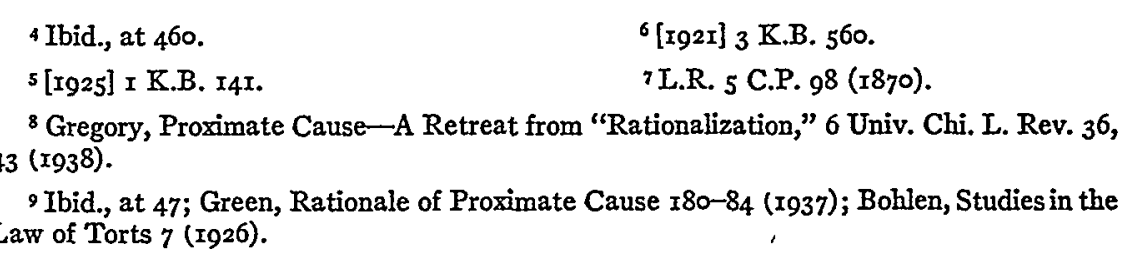

so [r933] A.C. $449,46 r$.

II [r933] A.C. $449,46 r$.

12 Harper, Torts \& II3, II6 (I933). 
person fires across a road when it is dangerous to do so and kills a man who is in receipt of a large income, he will be held liable for the whole damage, however great, that may have resulted to his family and cannot set up that he could not have reasonably expected to have injured anyone but a laborer." , $_{3}$

If the Liesbosch case foreshadowed the abandonment of the Polemis doctrine, the dictum in the Monarch case seems to be a fulfillment of that prophecy. For the English court made special effort to discuss a rule of damages, applicable to both contract and tort, in a case which could easily have been decided on ordinary principles of contract liability. Lord Wright phrased the issues thus: "In the Liesbosch case it was held that loss due to impecuniosity was too remote, and, therefore, to be neglected in the calculation of damages. It was special loss due to financial position. A different conclusion was arrived at in Mohammed Issa el Sheikh Ahmad v. Ali, . . where damages consequent on impecuniosity were held not too remote, because, as I understand, the loss was such as might reasonably be expected to be in the contemplation of the parties." ${ }^{4}$ Since the remoteness of impecuniosity was in question in both of these cases, the different results cannot be based on a theory of actual causation, but rather seem to be based on the theory of "reasonable contemplation." In view of the fact that on its merits the Monarch case hardly warranted review by the House of Lords, the full effect of such a dictum cannot be underestimated.

Generally, the rules and doctrines relating to proximate cause are mainly to determine whether liability exists at all. But, as in the Liesbosch situation, they are also used in deciding questions of damage-that is, questions of responsibility for particular items of loss or injury. ${ }^{16}$ Thus, in the final analysis, the question of proximate cause in this situation is one of the extension of liability for a negligent act. Perhaps the court in the Monarch case was looking for a more practical test in the rule of "reasonable contemplation." ${ }^{37}$ But the "reasonable contemplation" doctrine strongly resembles the so-called "Pennsylvania" rule of proximate cause, which tests only whether the ultimate or particular harm in question itself was foreseeable, probable, and natural. Such a test not only repudiates the Polemis rule but is as extreme in prohibiting liability as the Polemis rule was in granting it. More than a repudiation, the Monarch case may support complete reversal of a traditional policy of tort liability.

Even though the "but for" test has been regarded as fairly clearcut, understandable and easy to apply, ${ }^{18}$ the English court in the Liesbosch case found it necessary to enter into a discussion of intervening agency in order to limit the near-absolute liability which the test would have demanded.9 Swayed by con-

${ }^{13}$ Smith v. London \& Southwestern R. Co., I.R. 5 C.P. 98 (1870).

${ }^{34}$ [I949] I All E.R. I, I4.

25 See Note, 64 L.Q. Rev. 2 (1948).

${ }^{16} \mathrm{McC}$ Cormick, Damages $\$ 72$ (r935).

${ }^{77}$ See Note, 65 L.Q. Rev. I (1949).

${ }^{18}$ Gregory, Proximate Cause-A Retreat from "Rationalization," 6 Univ. Chi. L. Rev. 36, 47 (I938).

19 See 38 L.Q. Rev. 165 (1922). 
siderations of equity, the House of Lords resorted to such an evasion in order to mitigate the harshness of the Polemis rule. Under a more rational approach to the question of the extension of liability such devices would not have been necessary. A test similar to that proposed by Judge Cardozo in Palsgraf v. Long Island $R$. Co..$^{20}$ does not demand any speculation on the question of intervening agency or conditions, and is an intermediate position between the theoretical statement of the English view and its opposite, the Pennsylvania view-the apparent logical end result of the "reasonable contemplation" test. If Judge Cardozo's "risk" or "hazard" approach had been applied in the Liesbosch case, the only question for the judge would be whether the harm suffered by the plaintiff was within the orbit of the foreseeable hazard or risk created by the defendants' negligence. Such a test, based on the element of foreseeability, may not appear so mechanical, but it would avoid philosophical speculation.

Perhaps the dictum in the Monarch case is indicative of a tendency in English law to place the question of proximate cause on a more rational basis, since the element of foreseeability plays a greater part. The determination of the extent of liability for a negligent act depends, in part, on certain values and concepts of social policy held by the court. An attempt to limit the liability under a rule based on actual causation, as in the Liesbosch case, led the court into a discussion of the concept of intervening agency, which submerged the question of policy. A test based on foreseeability or on reasonable contemplation necessarily makes room for the values and concepts of social policy held by the judge. A question of what is reasonably foreseeable is not only based on the judge's past experience, but also on notions of what should be, and thus on policy considerations. $^{2 \pi}$

Perhaps the "reasonable contemplation" test, as enunciated in the Monarch case, will place the law of damages in negligence on a more practical and rational basis, if the end result will be a position similar to the intermediate "Cardozo" view. But if the final conclusion will be analagous to the "Pennsylvania" view, the English courts will have done an "about face" and exchanged one extreme position for another equally as extreme.

\section{JURISDICTION OF STATES UNDER BLUE-SKY LAWS}

Travelers Health Association, incorporated under the laws of Nebraska with its home office in Omaha, had in force in Virginia approximately eight hundred membership certificates providing health insurance protection. The association never had any office, agent or property in Virginia. The customary method for soliciting new memberships was for existing members to recommend to the

${ }^{20} 248$ N.Y. 339 , I62 N.E. 99 ( 1928 ).

${ }^{2 x}$ Gregory, Proximate Cause-A Retreat from "Rationalization," 6 Univ. Chi. L. Rev. 36,5 ( $(9938)$. 
association likely prospects who were then by mail invited to apply for membership. An interested prospect would fill out an application blank and mail it to the Omaha office. After acceptance of the application there, a membership certificate would be returned to him by mail, subject to his approval. The Virginia State Corporation Commission charged the association with selling securities without procuring a permit from the commission as required by the Virginia Blue-Sky Law. After service of process by registered mail, the association through its attorneys appeared specially before the commission for the sole purpose of contesting the jurisdiction of the state. The association contended it had conducted no business activities within Virginia, but had transacted its entire business outside the state through the mails, and that service of process by registered mail was therefore insufficient. Concluding that the activities of the association violated the Blue-Sky Law and were sufficient to bring it within the jurisdiction of the state, the commission ordered the association to cease and desist from offering, promoting or selling further certificates in Virginia without the required permit. On appeal, the Virginia Supreme Court sustained the jurisdiction of the commission and the sufficiency of the service. Travelers Health Ass'n v. Commonwealth. ${ }^{2}$

This case raised the problem of what contacts a foreign business must have with a state to be subject to the jurisdiction of the state to regulate and the jurisdiction of the state courts and administrative agencies to enforce such regulation. While the general problem is a familiar one, the instant case presented the borderline situation of a business conducted by an interstate medium of communication without physical entry into the state. The decision applied the broad doctrine proclaimed in International Shoe Co.v. Washington ${ }^{3}$ that a foreign corporation may be subject to the jurisdiction of a state whenever its operations have established sufficient contacts with the state to make the jurisdiction reasonable and just according to traditional notions of fair play and substantial justice. The present decision, furthermore, was an extension of the idea that jurisdiction may be based on conduct having probable serious consequences within the state, such contact making state action for the protection of its citizens reasonable. Practical complications which may result from these extensions also are suggested by the decision.

In view of the broad jurisdictional requirement laid down in the International Shoe decision, the outcome of the present case is not startling. The Virginia Supreme Court was able to base jurisdiction on four contacts with the state: (I) encouragement and ratification by the association of the activities of its members within the state in soliciting new members, (2) investigations of claims made within the state, (3) remittance of benefits within the state, and (4) final

Ya. Code Ann. (Michie, I942) \& 3848(47)-(66).

${ }^{2} x 88$ Va. 877 , 51 S.E. $2 d{ }_{26}$ (1949), probable jurisdiction noted, 69 S. Ct. 4496 (x949).

${ }^{3} 326$ U.S. 3 ro (1945). 
acceptance of the offer of membership within the state. 4 Unlike the defendant in the International Shoe situation, however, the defendant in the present case had no legally constituted agents soliciting within the state.

In arriving at its decision, the court made a departure from a r923 ruling of the United States Supreme Court in the closely similar case of Minnesota Commercial Men's Ass' $n$ v. Benn. In that case all the above contacts, except possibly the fourth, were present. Yet such activities were held not to constitute doing business within the state sufficient for jurisdiction to award a judgment by default after service of process on the Secretary of State in accordance with a Montana insurance statute. While the Benn case had been distinguished in a recent federal mail-order insurance decision, ${ }^{6}$ as recently as 1947 the Missouri Supreme Court in a similar mail-order insurance case, without mention of the International Shoe case, relied on the doing-business requirement of the Benn case to deny jurisdiction. ${ }^{7}$ Although the activities of the association in the present case could hardly have been better tailored to fit the situation in the Benn case, it was distinguished by the Virginia court on the tenuous basis that the action there was for a pecuniary civil judgment while in the present case it was of a "quasi-criminal" nature.

The circumvention of the Benn decision is an indication that state courts are willing to abandon old concepts of doing business which were set up as requirements for jurisdiction prior to the International Shoe case. In order to ignore the United States Supreme Court precedent in the Benn case, which had lost most of its force as a result of the International Shoe decision, the present opinion resorted to some window dressing of questionable value. The court, for example, relied on the United States Supreme Court decision in Merrick v. Halsey $\& \mathrm{Co} .,{ }^{8}$ which upheld the constitutionality of application of a Michigan Blue-Sky Law against certain foreign businesses, including a partnership which had solicited stock purchases within the state by mail. The decision is, however, far from conclusive in the present case because, among other reasons, the question of jurisdiction for service of process was not at issue. ${ }^{9} \mathrm{~A}$ still weaker basis for the present

4 This last was an attempt to show that Virginia was the place of contracting, i.e., the place of the last act necessary to the completion of the contract. I Williston, Contracts $\$ 97$ (1936). In the case of insurance contracts, however, this is usually the place where the acceptance of the application for insurance is mailed. Richards, Insurance $\$ 76$ (1932). Even though the insured could reject the certificate in the present case, it would seem that the latter rule should determine the place of contracting if coverage is provided from the time of mailing of the acceptance.

$s_{26}$ I U.S. 140 (I923).

${ }^{6}$ Storey v. United Insurance Co., 64 F. Supp. 896 (I946). There the statute providing for service of process on the secretary of state in effect defined doing business as delivery of policies, and the policies involved there had stipulated that they would not be in force until delivery.

7 Cindrich v. Indiana Travelers Assurance Co., $35^{6}$ Mo. I064, 204 S.W. $2 d 765$ (I947).

8242 U.S. 568 (rgI7).

- The partnership had intervened voluntarily. 
decision was the argument by the court that the commission, under another section of the statute, could probably have obtained extradition of the defendant upon information or indictment, and it therefore had jurisdiction to serve process by registered mail. This conclusion is not only a non sequitur, but is based on a premise which assumes the validity of a statutory provision on which there may be some question.

A more sound basis for jurisdiction for service of process was founded on the inherently serious consequences of the defendant's activity. At the outset the court was careful to point out that the regulation of the promotion and sale of securities is a proper exercise of the police power of the state. Service by registered mail to enforce such regulation was analogized to the well-established practice under nonresident motorist statutes approved in Hess v. Pawloski. ${ }^{\text {.0 }}$ This analogy can be supported by Doherty \& $C o$. v. Goodman ${ }^{\text {II }}$ which recognized the exceptional nature of the business of dealing in corporate securities and held valid the service of process on a nonresident dealer by service on an agent within the state without actual personal service. The present decision, however, goes farther than either of these cases, since neither the defendant nor the defendant's agents entered the state, and the conduct was carried on principally from without the state.

Strong support for the outcome of the present case can be found in decisions on the problem of whether a state has power to apply its regulations to a foreign corporation. The two problems are practically indistinguishable. Both the existence of jurisdiction and of the power to regulate depend upon the amount of contacts the foreign corporation has with the state, and in either case a broad test is now applied by the United States Supreme Court. Thus in Hoopeston Canning Co. v. Cullen ${ }^{\mathrm{x}^{2}}$ a foreign insurance company was held subject to regulation by New York even though the company had no agents, offices or property within the state, and the formalities of the transactions were carried on by mail from Chicago. There the power to regulate was determined by the location of activity prior and subsequent to the making of the contract, and by the degree of interest of the regulating state in the object insured. Theories of place of contract or performance, which had become involved in earlier determinations of the power of a state to apply its own regulatory laws to insurance business activities, were brushed aside as "conceptualistic." In place of those factors the Court substituted the more realistic considerations laid down in Alaska Packers Ass'n v. Industrial Accident Commission: ${ }^{23}$ the protection of the citizen insured and the protection of the state from the incidents of loss. The Hoopeston decision, consequently, has considerably weakened the line of cases based on Allgeyer $v$. Louisiana, ${ }^{\mathrm{T}} \mathrm{w}$ wich had excused mail-order insurance from regulation

${ }_{20} 274$ U.S. 352 (1927).
${ }^{12} 294$ U.S. 623 (1935).
${ }^{22} 318$ U.S. 313 (r943).

${ }^{13} 294$ U.S. 532 (1935).

${ }^{4} x_{5}$ U.S. 578 (1897). 
because the contracts were not made within the state and business was not being done within the state.

Thus it can be seen that there has been a parallel relaxation of requirements both for regulation and for jurisdiction. The trend is toward increasing the discretion of the states, restrained only by the vague limit of reasonableness. Should the trend be universally followed, there would be little possibility left for foreign corporations to sell securities to citizens of a state and still avoid its Blue-Sky or other regulatory laws. ${ }^{15}$ While it was possible in the present case for the court to rely on several "activities" within the state, it would seem from the Hoopeston decision that the mere fact that the purchasers were within the state should be the essential factor. The seriousness of the possible consequences to securities purchasers would contribute to this result. Place of contracting, ${ }^{16}$ presence of the defendant within the state, ${ }^{17}$ and implied consent ${ }^{18}$ are no longer controlling factors. It may be inferred, moreover, that jurisdiction would be recognized over individuals or partnerships engaged in activities similar to those in the present case, since the decision placed no reliance on the fact that the seller was a corporation. ${ }^{19}$ In the application of Blue-Sky Laws this is of special importance since dealers in securities frequently fall into the former two categories.

The wide discretion being given to the states is desirable if the states are to protect their citizens effectively. Under the old requirement of doing business or of making contracts, it was a simple matter for a business to escape undesirable regulation by arranging the formalities of transactions outside the state. ${ }^{20}$ Since Nevada has no Blue-Sky Law $_{2}{ }^{2 x}$ and since several states merely provide remedies for fraud, ${ }^{22}$ states requiring licensing of dealers and registration of se-

Is A probable exception would be where the purchase was completely carried out by a broker-agent physically outside the state and where none of the solicitation or negotiation was within the state. Compare Jones v. Re Mine Oil Co., 47 Cal. App. 2d 832, Irg P. 2d 219 (I94I).

${ }^{16}$ Basis for decision in Minnesota Commercial Men's Ass'n v. Benn, 26r U.S. I40 (I923).

${ }_{77}$ Basis for decision in International Harvester Co. v. Kentucky, 234 U.S. 579. (rgr4).

${ }^{8}$ Basis for decision in Lafayette Insurance Co. v. French, I8 How. (U.S.) 404 (I856).

19 Jurisdiction could be based on the "dangerous activity" concept of Hess v. Pawloski, 274 U.S. 352 (r927), and Doherty v. Goodman, 294 U.S. 623 (I935), without regard to the form of the business organization. The inference that partnerships and individuals would be similarly subject to jurisdiction is also supported by the reliance the court placed on Merrick v. N. W. Halsey \& Co., 242 U.S. 568 (I9I7), which it interpreted as holding that a state may regulate a foreign partnership selling securities within the state by mail.

${ }^{20}$ In hearings on the Federal Securities Act this method of avoidance was cited as one of the reasons why federal regulation was needed. Hearings Before the Committee on Interstate and Foreign Commerce on H.R. 43I4, 73rd Cong. Ist Sess., at roo-or (r933).

${ }^{2 x}$ The District of Columbia has no Blue-Sky Law as such, the Securities Act of 1933 being the principal legislation.

22 The Delaware Act is an example. Del. Rev. Code (I935) § 4369 . 
curities $^{23}$ might well feel that the regulation provided by sister states would be inadequate.

This award of discretion to the states, nevertheless, carries with it certain potential drawbacks. As a result of the lack of uniformity in state regulations, the legality of the same method of conducting business may be inconsistently determined in different states. In the case of Blue-Sky Laws, the handling of securities issues may be accompanied by additional delay and expense as a result of registration and qualification requirements in many states. In states where the demand for new issues is not great, this delay and expense may keep out otherwise acceptable issues.

While the result in the present case may be necessary for effective state regulation of securities sales, there remains the question of whether, in view of the above disadvantages, it is desirable to have such regulation in the hands of the states at all where transactions affecting more than one state are involved. In early cases attacking state Blue-Sky Laws as an unconstitutional burden on interstate commerce, the United States Supreme Court upheld the legislation as a valid exercise of the states' police power. ${ }^{24}$ While the unreasonableness of the burden has thus been denied, the existence of some burden must be admitted. Moreover, whenever transactions involve elements from more than one state, as in the present case, any civil litigation for recission arising therefrom may present a choice-of-laws problem. Cases in which this problem has been raised have produced a variety of conflicting rules as to what law should govern. ${ }^{2} 5$ Regulation by the states perpetuates this uncertainty and lack of uniformity. Exclusive federal regulation of securities sales would eliminate the cost and delay of complying with many state laws and would give interstate securities dealers a uniform regulation, while still providing the necessary protection to purchasers. Unfortunately, the present Federal Securities Act does not accomplish these objectives. ${ }^{26}$ First, it explicitly provides that nothing in the act shall affect the jurisdiction of any state securities commission. ${ }^{27}$ Thus instead of simplifying securities regulation, the act has complicated it still further. Overlapping state regulation could be eliminated by a provision that any state regulation on any subject covered by the federal act shall be superseded thereby. A second shortcoming of the federal act is that it does not provide all the protection for purchasers which might be desired. Thus a recent narrow interpretation

${ }^{23}$ The Ohio and Illinois Acts are examples. Ohio Code Ann. (Throckmorton, I948)

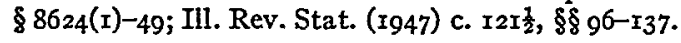

${ }^{24}$ The Blue-Sky cases. Hall v. Geiger-Jones Co., 242 U.S. 539 (rgr7); Caldwell v. Sioux Falls Stock Yards Co., 242 U.S. 559 (I9I7); Merrick v. Halsey \& Co., 242 U.S. 568 (I9I7).

${ }_{25}$ Determination of the Validity of Interstate Transactions: State Blue-Sky Laws, $5 \mathrm{r}$ Harv. L. Rev. I55 (1937); Liability for Interstate Sales of Securities under State Blue-Sky Laws, 3 I Calif. L. Rev. 95 (1942).

${ }^{26} 48$ Stat. $74-92$ (1933), 15 U.S.C.A. $\$ 77$ (a)-(aa) (1941).

${ }^{27} 48$ Stat. 85 (r933), ${ }_{5}$ U.S.C.A. $\$ 77(\mathrm{r})$ (r94r). 
of the federal act by the Court of Appeals for the Seventh Circuit denied the protection of the act to a purchaser where the misrepresentations sued on were made neither by means of some interstate method of communication nor by means of the mails, although the transaction came within the purview of the act in other respects. ${ }^{28}$ This defect could be overcome by a provision that civil and penal remedies shall be available for any misrepresentation made by any means and in any connection with a sale of securities by means of interstate communication or of the mails.

But the securities selling industry probably would find exclusive control in the federal government more distasteful than inconsistent state regulation. Furthermore, wide divergence exists as to what exclusive federal regulations should contain. Therefore perhaps the most satisfactory solution that can be hoped for would be the inclusion of provisions in the state acts requiring state administrative agencies to accept for their mechanical requirements copies of documents prepared pursuant to the federal act, and requiring exercise of regulatory powers on the basis of information therein. ${ }^{29}$

It seems likely that the zeal of the state courts for protecting state citizens will cause these courts to follow the lead of the Virginia court in the present case and take full advantage of the wide discretion given them in the International Shoe and Hoopeston decisions. Pending disposition of the present case by the Supreme Court of the United States may settle the matter. ${ }^{30}$ As it stands, in the absence of the suggested federal legislation or of specific exemptions in the state acts, dealers in interstate securities transactions by mail, telephone or telegraph probably will be forced to comply with the Blue-Sky Laws of every state in which they have purchasers. The result will be the exercise by the states of a significant portion of the power delegated to Congress by the Constitution of the United States to regulate commerce among the states..$^{3 x}$

\section{LIMITATION OF SHIPOWNERS' LIABILITY: SUBSTANCE OR PROCEDURE?}

According to early maritime codes and the subsequent general maritime law, the liability of a shipowner was limited to his interest in the ship. ${ }^{x}$ But since the nineteenth century decline of the general maritime law, diverse methods of com-

${ }^{28}$ Kemper v. Lohnes, 773 F. $2 d 44$ (C.A. 7 th, 7949 ).

${ }_{29}$ Compare the present Indiana provisions. Ind. Stat. Ann. (Burns, I933) $\$ 25-836$ (cc).

${ }^{3 \circ}$ Probable jurisdiction has been noted and the case transferred to the summary docket. 69 S. Ct. 1496 (1949).

${ }^{3 x}$ U.S. Const. Art. I, § 8.

The Consolato del Mare, probably compiled by private individuals in the Middle Ages by order of the kings of Aragon, "'expressly limits the liability of the part owner to the value of his share in the ship." The Main v. Williams, I52 U.S. I22, I26 (I894). This code eventually "became the common law of all the commercial powers of Europe." 3 Kent Comm. xo; see The Rebecca, 20 Fed. Cas. 373, No. Ir, 619 (D.C. Me., I83r). 